\title{
Phytochemical Analysis and Antimicrobial Activity of Four Different Extracts from the Leaves of Murraya koenigii
}

\author{
M. Victoriya Salomi ${ }^{1,2 *}$ and R. Manimekalai ${ }^{2}$ \\ ${ }^{1}$ Research Scholar, Department of Biotechnology, Mother Terasa Womens University, \\ Kodaikanal, India \\ ${ }^{2}$ Department of Biochemistry and Bioinformatics, Dr.MGR Janaki college of Arts and Science \\ for Women, Chennai-600028, Tamil Nadu, India \\ *Corresponding author
}

A B S T R A C T

Keywords

Murraya koenigii,

Rutaceae,

phytochemicals, antimicrobial

activity,

antifungal activity.

\section{Article Info}

Accepted:

25 June 2016

Available Online:

10 July 2016
Four different extracts of Murraya Koenigii(Rutaceae) leaves were screened for their phytochemical composition and antimicrobial activity. The present study investigates the qualitative and quantitative analysis of the major phytochemicals in four different extracts of Murraya Koenigii. The constituents screened for were tannins, saponins, flavanols, flavonoids, total phenolic compounds, proanthocyanidins, carotenoids, alkaloids, glycosides, reducing sugars and aminoacids. The antimicrobial activity of the extracts against Methicillin Resistant Staphylococcus aureus, Micrococcus luteus, Bacillus subtilus, Psedomonas aeruginosa, Escherichia coli, Candida albicans and Aspergillus Niger were screened. The study shows that all the extracts posses' remarkable antimicrobial and antifungal activity.

\section{Introduction}

Phytochemicals are natural bioactive compounds found in plants and these are divided into two groups; primary and secondary compounds. These classes perform functions in plant metabolism. Amino acids, sugars, proteins and chlorophyll are known as primary compounds while secondary compounds consists of alkaloids, terpenoids, phenolic compounds etc.(Krishnaiah et al., 2009) Since human's existence on planet, man has been dependent on nature for curing various diseases. Herbal medicine has proved efficacious and potent in the treatment of many chronic diseases that orthodox medicine cannot cure. Plants have the ability to synthesize a wide variety of chemical compounds that are used to perform important biological functions, and to defend against attack from predators such as insects, fungi and herbivorous mammals. Many of these phytochemicals have beneficial effects on long-term health when consumed by humans, and can be used to 
effectively treat human diseases. The use of herbs to treat disease is almost universal among non-industrialized societies, and is often more affordable than purchasing expensive modern pharmaceuticals.

Murraya Koenigii (Rutaceae) is a tropicalto sub-tropical tree which is native to India and Sri-Lanka.The family Rutaceae has more than150 genera and 1600 species (Krishnaiah et al., 2009). The plant is a rich source of carbazole alkaloids (Sathyavati et al., 1978).Its leaves are used in many dishes as curry leaves. The leaves are pinnate, with 11-21 leaflets, each leaflet $2-4 \mathrm{~cm}$ long and $1-2 \mathrm{~cm}$ broad. They are highly aromatic. Curry leaves have many medicinal properties. It stimulates digestive enzymes and helps in breakdown of food more easily, good remedy for nausea and indigestion. It also improves eye-sight and prevents cataract. Eating curry leaves lowers blood glucose level. The benefits of curry leaves also owe to its flavour and taste and are added to dishes to enhance the smell, taste and its value.

Phytochemical studies on the leaves, stem, bark and root of this plant have shown the presence of large concentration of alkaloids, phenolic compounds and very high radical scavenging activity (Kumar et al., 1999; Sharif et al., 2007). The antioxidant activity of curry leaf is attributed to mahanimbine, murrayanol and mahanine (Sharif et al., 2007; Tachibana et al., 2001).

Health benefits of Murraya Koenigii leaves are anti-diabetic (Ningappa et al., 2008), antioxidant (Kesari et al., 2005), antimicrobial (Vandana et al., 2012), antiinflammatory (Ningappaa et al., 2008), hepatoprotective (Darvekar et al., 2011), anti-hypocholestremic \& hypolipidemic (Gupta et al., 2007), anti-diaarhoel(Iyer et al., 1990), cytotoxic (Mandal et al., 2010) antidementia (Nutan et al., 1998) etc.
The present study investigate the comparision of qualitative and quantitative analysis of the different constituents \& antimicrobial activity of four different extracts of Murraya Koenigii.

\section{Materials and Methods}

\section{Plant materials}

Fresh leaves of Murraya Koenigii were collected from Ponneri, Thiruvallur district, Tamilnadu, India during the month of September. The collected leaves were identified taxonomically and authenticated by Dr. G. Jeya Jothi, Taxonomist, Department of Plant Biology and Biotechnology, Loyola College, Chennai. A voucher specimen (No: LCH 401) was deposited at Herbarium, Department of Plant Biology \& Biotechnology, Loyola College, Chennai. The leaves were washed thoroughly 2-3 times with running tap water and once with sterile water, air dried, powdered and used for extraction.

\section{Preparation of plant extract}

$50 \mathrm{~g}$ of air dried and coarsely powdered plant material was extracted successively with $100 \mathrm{ml}$ of methanol, water, acetone and hexane using a soxhlet's apparatus for 48 hrs each. The four crude extracts were stored at 5degrees in labelled sterile screw-capped bottles for further use.

\section{Preliminary phytochemical analysis}

\section{Qualitative analysis of Phytochemicals}

Initial screening test of the four extracts were performed to ascertain the presence or absence of phytoconstituents such as flavonoids, flavonols, tannins (Ferric chloride test \& lead acetate test) saponins (Frothing test), anthraquinones (Brontrager's 
test), steroids (Salkowski test and LibarmanBurchard's test), glycosides, sugars, amino acids and alkaloids (Dragendroff's test, Meyer's test, Hager's test, and Wagner's test) using standard procedure (Mani et al., 2012; Sofowora et al., 1993; Somolenski et al., 1974).

Quantitative Phytochemicals

\section{Determination of total phenolic content}

Total phenol contents in the various extracts were determined by the modified FolinCiocalteu method of Zovko et al (Zovko et al., 1973). An aliquot of $0.5 \mathrm{ml}$ of each extract $(1 \mathrm{mg} / \mathrm{ml})$ was mixed with $2.5 \mathrm{ml}$ Folin-Ciocalteu reagent (previously diluted with distilled water $1: 10 \mathrm{v} / \mathrm{v})$ and $2 \mathrm{ml}(75 \%$ w/v) of sodium carbonate $\left(\mathrm{Na}_{2} \mathrm{CO}_{3}\right)$. The tubes were vortexed for $15 \mathrm{~s}$ and allowed to stand for $30 \mathrm{~min}$ at $40^{\circ} \mathrm{C}$ for colour development. Absorbance was then measured at $765 \mathrm{~nm}$ using Hewlett Packard, UV/visible light spectrophotometer. Samples of extract were evaluated at a final concentration of $1 \mathrm{mg} / \mathrm{ml}$. Total phenolics content were expressed as $\mathrm{mg} / \mathrm{g}$ tannic acid equivalent using the following equation from the calibration curve: $Y=0.1216 \times$, $\mathrm{R}^{2}=0.936512$, where $\mathrm{x}$ is the absorbance and $\mathrm{Y}$ is the tannic acid equivalent in $\mathrm{mg} / \mathrm{g}$.

\section{Determination of total flavonoids}

The method is based on the formation of the flavonoids - aluminium complex which has an absorptivity maximum at 420nmdescribed by Ordonez et al (Ordonez et al., 2010).Half a $\mathrm{ml}$ of various solvent extracts $(1 \mathrm{mg} / \mathrm{ml})$ was mixed with $0.5 \mathrm{ml}$ of $2 \%$ aluminium chloride $\left(\mathrm{AlCl}_{3}\right)$ prepared in ethanol. The resultant mixture was incubated for $60 \mathrm{~min}$ at room temperature for yellow colour development which indicated the presence of flavonoid. The absorbance was measured at $420 \mathrm{~nm}$ using UV-VIS spectrophotometer. Extract samples were evaluated at a final concentration of 1 $\mathrm{mg} / \mathrm{ml}$. Total flavonoid content was calculated as quercetin equivalent $(\mathrm{mg} / \mathrm{g})$ using the following equation based on the calibration curve: $\mathrm{Y}=0.255 \mathrm{x}, \mathrm{R}^{2}=0.9812$, where $X$ is the absorbance and $\mathrm{Y}$ is the quercetin equivalent.

\section{Estimation of total flavonols}

Total flavonol content was determined by adopting the procedure described by Karunakaran and Kumaran (Karunakaran $e t$ al., 2007). The reaction mixture consisting of $2 \mathrm{ml}$ of the sample, $2 \mathrm{ml}$ of $\mathrm{AlCl}_{3}$ prepared in ethanol and $3 \mathrm{ml}$ of $(50 \mathrm{~g} / \mathrm{l})$ sodium acetate solution was allowed to incubate for $2.5 \mathrm{~h}$ at $20^{\circ} \mathrm{C}$.

Absorbance at $440 \mathrm{~nm}$ was measured. Total flavonol content was calculated as $\mathrm{mg} / \mathrm{g}$ of quercetin equivalent from the calibration curve using the equation: $Y$ $\mathrm{Y}=0.0255 \times, \mathrm{R}^{2}=0.9812$ where $\times$ is the absorbance and $\mathrm{Y}$ is the quercetin equivalent.

\section{Estimation of proanthocyanidins}

Proanthocyanidins contents was estimated by the procedure done by Asafa et al (Ashafa et al., 2011).A volume of $0.5 \mathrm{ml}$ of each extract solution was mixed with $3 \mathrm{ml}$ of $4 \% \mathrm{v} / \mathrm{v}$ vanillin prepared in methanol and $1.5 \mathrm{ml}$ of hydrochloric acid and then vortexed. The resulting mixture was allowed to stand for $15 \mathrm{~min}$ at room temperature followed by the measurement of the absorbance at $500 \mathrm{~nm}$. Total proanthocyanid in content was expressed as catechin $(\mathrm{mg} / \mathrm{g})$ using the following equation of the curve: $\mathrm{Y}=0.5825 \times, \mathrm{R}^{2}=0.9277$, where $\mathrm{x}$ is the absorbance and $\mathrm{Y}$ is the catechin equivalent. 


\section{Tannin determination}

Tannin content of the samples was determined according to the modified vanillin- $\mathrm{HCl}$ methanol method as determined by Noha et al (Noha et al., 2011).The vanillin-HCL reagent was prepared by mixing equal volume of $8 \%$ $\mathrm{HCl}$ and $1 \%$ vanillin in methanol. The reagent was mixed just prior to use. About $0.2 \mathrm{~g}$ of the ground sample was placed in a small conical flask. Then $10 \mathrm{ml}$ of $1 \%$ concentrated HCL in methanol was added. The flask was capped and continuously shaken for $20 \mathrm{~min}$ and the content was further centrifuged at $2500 \mathrm{rpm}$ for $5 \mathrm{~min}$. About $1.0 \mathrm{ml}$ of the supernatant was pippetted into a test tube containing $5 \mathrm{ml}$ of vanillin-HCL reagent. Absorbance at 450 $\mathrm{nm}$ was read on spectrophotometer after 20 min of incubation at $30^{\circ} \mathrm{C}$. A standard curve was prepared expressing the result as catechin equivalent as follows: Tannin (\%) $=\mathrm{C} \times 10 \times 100 / 200$. Where: $\mathrm{C}=$ Concentration corresponding to the optical density; $10=$ volume of the extract $(\mathrm{ml})$; $200=$ Sample weight $(\mathrm{mg})$.

\section{Saponin determination}

Five grams of plant sample was dispersed in $50 \mathrm{ml}$ of $20 \% \mathrm{v} / \mathrm{v}$ ethanol prepared in distilled water. The suspension was heated over hot water bath for $4 \mathrm{~h}$ with continuous stirring at $55^{\circ} \mathrm{C}$. The mixture was filtered and the residue re-extracted with another 50 $\mathrm{ml}$ of $20 \%$ ethanol. The combined extracts were reduced to $20 \mathrm{ml}$ over hot water bath at about $9^{\circ} \mathrm{C}$. The concentrated solution obtained was shaken vigorously with $10 \mathrm{ml}$ of diethyl ether in a $250 \mathrm{ml}$ separating funnel; the aqueous layer was collected while the ether layer was discarded. The purification process and repeated. Twenty millilitre of but-1-ol was added to the filtrate and then washed twice with $10 \mathrm{ml}$ of $5 \%$ w/v aqueous sodium chloride. The whole mixture was heated to evaporation on hot water bath and later oven dried at $40^{\circ} \mathrm{C}$ to a constant weight. The percentage saponin content of the sample was calculated using the formula described by Okwu and Josiah (Okwu et al., 2006)

\section{Alkaloid determination}

Alkaloid content of the plant sample was determined using the method described by Onyilagha and Islam (Onyilagha et al., 2009). Five gram of the powdered sample was weighed into a $250 \mathrm{ml}$ beaker and 200 $\mathrm{ml}$ of $20 \%$ acetic acid in ethanol was added and covered to stand for $4 \mathrm{~h}$. This was filtered and the extract was concentrated using a water bath to one-quarter of the original volume. Concentrated ammonium hydroxide was added drop wise to the extract until the precipitation was completed. The whole solution was allowed to settle and the collected precipitates were washed with dilute ammonium hydroxide and then filtered. The residue was dried and weighed. The alkaloid content was determined using this formula;

$\%$ Alkaloid=final weight of sample

Initial weight of extract $\times 100$.

\section{Sources and maintenance of organisms}

Stock cultures of Methicillin Resistant Staphylococcus aureus, Micrococcus luteus, Bacillus subtilus, Pseudomonas aeruginosa, Escherichia coli, Candida albicans and Aspergillus Niger were obtained from Department of Microbiology, Dr.MGR Janaki College, Chennai. They were maintained on Nutrient Agar at $4^{\circ} \mathrm{C}$ and subcultured into nutrient broth. Twenty four hour old cultures were prepared freshly for every study. 


\section{Antibacterial assay}

Antibacterial assay of four crude extracts were performed using Mueller Hilton medium for bacterial strains using disc diffusion method following the National Committee for Clinical Laboratory Standards methods (Trease, 1989; NCCLS, 1993).

\section{Disc Diffusion Assay}

The sterile petri dishes containing solid and sterile Mueller Hilton agar medium (HiMedia) were used. Sterile paper disc $(6 \mathrm{~mm})$ was saturated with $100 \mu$ land $200 \mu \mathrm{l}$ of four different extracts of Murraya Koenigii at a concentration of $1 \mathrm{mg}$ and $2 \mathrm{mg} /$ disc respectively and allowed to dry for $24 \mathrm{~h}$. The dried surface of the Mueller Hilton agar plate was streaked with the bacterial strain and dried discs were placed per Petri dish in triplicates. The plates were then incubated at $35^{\circ} \mathrm{C}$ for $24 \mathrm{~h}$. Positive and negative controls were performed for every test. For each plate, negative controls were maintained where pure solvents were used instead of extract. Ampicillin and streptomycin were used as positive control. Microbial growth was determined by measuring the diameter of the zone of inhibition with a caliper. The inhibition zones would thus include disc size of $6 \mathrm{~mm}$.

\section{Determination of antifungal activity}

The agar well diffusion method (King et al., 2001) was modified. Potato dextrose agar (PDA) was used for fungal cultures. The culture medium was inoculated with the fungal strain Aspergillus niger and Candida albicans separately suspended in potato dextrose broth. A total of $6 \mathrm{~mm}$ diameter wells were punched into the agar and filled with plant extracts and solvent blanks
Standard antibiotic (Fluconazole, concentration $1 \mathrm{mg} / \mathrm{ml}$ ) was used as positive control and fungal plates were incubated at $28 \mathrm{oC}$ for $48 \mathrm{~h}$. The diameters of zone of inhibition observed were measured. Antifungal activities were determined by measuring diameter of inhibition zone (DIZ) in $\mathrm{mm}$.

\section{Results and Discussion}

\section{Preliminary phytochemical analysis}

Phytochemical analysis of the four different extracts of murraya Koenigii revealed the presence of phenolic compounds, tannins, flavonols, flavonoids, proanthocyanidins, carotenoids, alkaloids, glycosides, sugars \& aminoacids.

\section{Quantification of phytochemicals}

Due to the vast differences in the nature of the phytochemical constituents found in a plant, there is no particular solvent that is known to extract all the compounds. Therefore in this study solvents like ethanol, water, acetone and hexane are used for extraction to accommodate the range of polarities of the compounds present in Murraya Koenigii leaves. The results showed that the choice of these various solvents play a crucial role in the quantitative analysis of different phytochemicals extracted from the leaves of Murraya Koenigii.

Quantification of compounds obtained from the extract varies greatly among the four solvents, which is an indication that solvents have different extracting capacity for phytochemicals. 
Table.1 Preliminary Phytochemical analysis of the four different extracts of Murraya Koenigii

\begin{tabular}{|c|c|c|c|c|c|c|c|c|c|}
\hline Sample & $\begin{array}{c}\text { Phenolic } \\
\text { compounds }\end{array}$ & Tannins & Flavonols & Flavonoids & $\begin{array}{c}\text { Proantho } \\
\text { cyanidins }\end{array}$ & Carotenoids & Glycosides & Sugars & Aminoacid \\
\hline $\begin{array}{c}\text { Ethanol } \\
\text { extract }\end{array}$ & ++ & +++ & +++ & +++ & ++ & ++ & ++ & + & ++ \\
\hline $\begin{array}{c}\text { Aqueous } \\
\text { extract }\end{array}$ & ++ & ++ & ++ & ++ & ++ & ++ & ++ & ++ & ++ \\
\hline $\begin{array}{c}\text { Acetone } \\
\text { extract }\end{array}$ & +++ & ++ & ++ & ++ & +++ & +++ & ++ & ++ & ++ \\
\hline $\begin{array}{c}\text { Hexane } \\
\text { extract }\end{array}$ & ++ & ++ & ++ & ++ & ++ & ++ & ++ & ++ & ++ \\
\hline
\end{tabular}

Table.2 Quantitative Phytochemicals evaluated of the four different extracts of Murraya koenigii

\begin{tabular}{|c|c|c|c|c|c|c|c|}
\hline Sample & $\begin{array}{c}\text { Total } \\
\text { Phenol } \\
(\mathrm{mg} / \mathrm{g})\end{array}$ & $\begin{array}{c}\text { Tannins } \\
(\mathrm{mg} / \mathrm{g})\end{array}$ & $\begin{array}{c}\text { Flavonols } \\
(\mathrm{mg} / \mathrm{g})\end{array}$ & $\begin{array}{c}\text { Flavonoid } \\
\mathrm{s} \\
(\mathrm{mg} / \mathrm{g})\end{array}$ & $\begin{array}{c}\text { Proantho- } \\
\text { cyanidins } \\
(\mathrm{mg} / \mathrm{g})\end{array}$ & $\begin{array}{c}\text { Saponin } \\
\mathrm{s} \\
(\mathrm{mg} / \mathrm{g})\end{array}$ & $\begin{array}{c}\text { Alkaloid } \\
\mathrm{s} \\
(\mathrm{mg} / \mathrm{g})\end{array}$ \\
\hline Ethanol extract & 142.32 & 73.95 & 91.13 & 45.76 & 774.72 & 62.33 & 49.09 \\
\hline Aqueous extract & 139.26 & 114.76 & 61.97 & 97.12 & 168.91 & 20.46 & 36.73 \\
\hline Acetone extract & 459.63 & 45.39 & 40.83 & 19.69 & 541.77 & 35.13 & 23.21 \\
\hline Hexane extract & 169.36 & 65.43 & 71.43 & 17.38 & 244.65 & 70.68 & 29.58 \\
\hline
\end{tabular}

Table.3 Antimicrobial activity of various extracts of Murraya koenigii

\begin{tabular}{|c|c|c|c|c|c|c|c|c|c|}
\hline \multirow[t]{2}{*}{ Microorganisms } & \multicolumn{2}{|c|}{ Methanol Extract } & \multicolumn{2}{|c|}{ Aqueous extract } & \multicolumn{2}{|c|}{$\begin{array}{l}\text { Acetone } \\
\text { Extract }\end{array}$} & \multicolumn{2}{|c|}{ Hexane Extract } & \multirow{2}{*}{$\begin{array}{c}\text { Positive } \\
\text { Control- } \\
\text { Ampicillin/ } \\
\text { streptomycin/ } \\
\text { Flucanazole }\end{array}$} \\
\hline & $\begin{array}{l}\text { Test } \\
(\mathrm{mm})\end{array}$ & $\begin{array}{l}\text { Solvent } \\
\text { Control }\end{array}$ & $\begin{array}{l}\text { Test } \\
(\mathrm{mm})\end{array}$ & $\begin{array}{l}\text { Solvent } \\
\text { Control }\end{array}$ & $\begin{array}{l}\text { Test } \\
(\mathrm{mm})\end{array}$ & $\begin{array}{l}\text { Solvent } \\
\text { Control }\end{array}$ & $\begin{array}{l}\text { Test } \\
(\mathrm{mm})\end{array}$ & $\begin{array}{l}\text { Solvent } \\
\text { Control }\end{array}$ & \\
\hline $\begin{array}{c}\text { Methicillin } \\
\text { Resistant } \\
\text { Staphylococcus } \\
\text { aureus }\end{array}$ & 14 & 2 & 11 & 0 & 13 & 1 & 14 & 1 & 18 \\
\hline $\begin{array}{c}\text { Micrococcus } \\
\text { luteus }\end{array}$ & 8 & 2 & 9 & 0 & 7 & 1 & 8 & 1 & 18 \\
\hline Bacillus subtilus & 10 & 2 & 10 & 0 & 9 & 1 & 11 & 1 & 18 \\
\hline $\begin{array}{c}\text { Psedomonas } \\
\text { aeruginosa }\end{array}$ & 14 & 2 & 9 & 0 & 12 & 1 & 13 & 1 & 18 \\
\hline Escherichia coli & 16 & 2 & 14 & 0 & 12 & 1 & 14 & 1 & 18 \\
\hline Candida albicans & 13 & 2 & 11 & 0 & 10 & 1 & 10 & 1 & 17 \\
\hline Aspergillus Niger & 11 & 2 & 10 & 0 & 9 & 1 & 10 & 1 & 17 \\
\hline
\end{tabular}


The antimicrobial activity of the extracts of Murraya koenigii leaves extracted using four different solvents was evaluated on the basis of inhibition zone in $\mathrm{mm}$. In the present investigation the extract was found to be effective against all the microorganisms.

All the extracts show antimicrobial activity and hence support the medicinal usage of the extracts of Murraya koenigii as drugs for the therapy of infectious diseases.

\section{References}

Ashafa, A.O.T., Sunmonu, O., Afolayan, A.J. 2011. Effects of leaf and berry extracts of Phytolacca dioica L on haematological and weight parameters of Wistar rats. Afri. J. Pharmacy and Pharmacol., 5: 150-154.

Darvekar, V.M., Patil, V.R., Choudhari, A.B. 2011. Anti-inflammatory activity of Murraya koenigii Spreng on experimental animals. J. Nat. Prod. Plant Res., 1(1): 65-69.

Gupta, R.S., Singh, D. 2007. Protective nature of Murraya Koenigii leaves against hepatosupression through antioxidant status in experimental rats. Pharmacologyonline, 1: 232-242.

Harbone, J.B. 1973. Phytochemical methods, London: Chapman and Hall, Ltd. 49-188.

Iyer, U.M., Mani, U.V. 2007. Studies on the effect of curry leaves supplementation (Murraya koenigi) on lipid profile, glycated proteins and amino acids in non-insulin-dependent diabetic patients. Plant Foods Hum. Nutr., 40(4) : 275-282.

Karunakaran, R.J., Kumaran, A. 2007. In vitro antioxidant activities of methanol extract of five phyllanthus species from India. $L W T$, 40: 344-353.

Kesari, A.N., Gupta, R.K., Watal, G. 2005. Hypoglycemic Effects of Murraya koenigii on Normal and AlloxanDiabetic Rabbits. J. Ethanopharmacol., 97: 247-251.

King, A., Brown, D.F.J. 2001. Quality assurance of antimicrobial susceptibility testing by disc diffusion. J. Antimicrob. Chemother., 48: 71-76. Krishnaiah, D., Devi, T., Bono, A., Sarbatly, R. 2009. Studies on phytochemical constituents of six Malaysian medicinal plants. J. Med. Plants Res., 3(2): 67-72.

Kumar, V.S., Sharma, A., Tiwari, R., Sushil, K. 1999. Murraya Koenigii- a review, JMAPS.

Mandal, S., Nayak, A., Kar, M., Banerjee, S.K., Das, A., Upadhyay, S.N. et al. 2010. Antidiarrhoeal activity of carbazole alkaloids from Murraya koenigii Spreng (Rutaceae) seeds. Fitoterapia, 8(1): 72-74.

Mani, V., Ramasamy, K., Ahmad, A., Parle, M., Shah, S.A., Majeed, A.B. 2012. Protective effects of total alkaloidal extract from Murraya Koeigii leaves on experimentally induced dementia. Food chem. Toxicol., 1036-44.

NCCLS. 1993. Performance Standards for Antimicrobial Disc Suspectibility Tests. Approved Standard NCCLS Publication M2-A5, Villanova, PA, USA.

Ningappaa, M.B., Dineshaa, R., Srinivasa, L. 2008. Antioxidant and free radical scavenging activities of polyphenolenriched curry leaf (Murraya koenigii L.) extracts. Food Chem., 106(2): 720728.

Ningappa, M.B., Ramadas, D., Leela, S. 2008. Antioxidant and free radical scavenging activities of polyphenolenriched curry leaf(Murraya Koenigii L.) extracts. Food Chem., 106: 720728.

Doi: 10.1016/j.foodchem.2007.06.057. 
Noha, A., Mohammed, I.A., Mohamed, A., Elfadil, E.B. 2011. Nutritional Evaluation of Sorghum Flour(sorghum bicolour L. Moench) during processing of Injera. World Acad. Sci. Engin. Technol., 75: 86-112.

Nutan, M.T.H., Hasnat, A., Rashid, M.A. 1998. Antibacterial and cytotoxic activities of Murraya koenigii. Fitoterapia, 69(2): 173-1751.

Okwu, D.E., Josiah, C. 2006. Evaluation of the chemical composition of two Nigerian medicinal plants. Afr. $J$. Biotech., 5: 357-361.

Oniyilagha, J.C., Islam, S. 2009. Flavonoids and other polyphenols of the cultivated spscies of the genus Phasaolus. Int. J. agric. Boil, 11: 231-234.

Ordonez, A.A.L., Gomez, J.D., Vattuone, M.A., Isla, M.I. 2006. Antioxidant activities of Sechium edule (Jacq) Food Chem. 97: 452-458.

Sathyavati, G.V., Gupta, A.K., Tendon, N. 1987. Medicinal Plants of India, Vol2, Indian Council of Medical Research, New Delhi India, 289-299.

Sharif, K., Khalid, U.K., Yusuf, M. 2007. Chemical constituents from stem barks and roots of Murraya
Koenigii(Rutaceae) Malays. J. Anal. Sci., 11: 173-176.

Sofowora, A. 1993. Medicinal plants and Traditionalmedicine in Africa: Spectrum Books Ltd, Ibadan, Ibadan, Nigeria, 289.

Somolenski, S.J., Silinis, H., Farnsworth, N.R. 1974. Lloydia, 37: 506-536.

Tachibana, Y., KIkuzaki, H., Lajis, H.N., Nakatani, N. 2001. Antioxidative activity of carbazoles from Murraya Koenigii leaves. J. Agric. Food Chem., 49: 5589-559994. Doi: 10.1021/jf010621r.[Pub med]

Trease, G.E., Evans, W.C. 1989. Pharmacognosy. 13th. Bailliere Tindall, Britain: English Language Book Society.

Vandana Jain, Munira Momin, Kirti Laddha Murraya Koenigii. 2012. An Updated Review. Int. J. Ayurvedic and Herbal Med., 2(4): 607-627.

Zovko, K.M., Kremer, D., Gruz, J., Strnad, M., Bisevac, G., Kosalec, I. 2010. Antioxidant and antimicrobial activities of Moltkia petraea (tratt.)Griseb. Flower, leaf and stem infusions. Food Chem. Toxicol., 48: 1537-1542.

\section{How to cite this article:}

Victoriya Salomi, M., and Manimekalai, R. 2016. Phytochemical Analysis and Antimicrobial Activity of Four Different Extracts from the Leaves of Murraya koenigii. Int.J.Curr.Microbiol.App.Sci. 5(7): 875-882. doi: http://dx.doi.org/10.20546/ijcmas.2016.507.100 